\title{
KEANEKARAGAMAN KEPITING BIOLA PADA KAWASAN HUTAN MANGROVE DESA KARIMUNTING KECAMATAN SUNGAI RAYA KEPULAUAN KABUPATEN BENGKAYANG
}

\author{
(Fiddler Crabs Diversity in Mangrove Forest Area of Karimunting Village Sungai Raya \\ Kepulauan District, Bengkayang Regency)
}

\author{
Hanafi, M. Sofwan Anwari, Ahmad Yani \\ Fakultas Kehutanan Universitas Tanjungpura. Jl. Daya Nasional Pontianak 78124 \\ E-mail: hanafi.coodees@gmail.com
}

\begin{abstract}
Karimunting Village is a coastal area that has a mangrove with contained several faunas in it, one of which is a fiddler crab. The fiddler crab is a Decapoda ordo and it is included in the Ocypodidae family. This study aims to collect data on the diversity of fiddler crabs in Karimunting Village. The method used in this study is a survey, while the sample is collected by applying the transect line with a purposive sampling technique. The transect line is $500 \mathrm{~m}$ length, with a total of three lanes. There are ten plots of 1x1 meter in size in each transect lines to pick up fiddler crabs. Fiddler crabs species were found in 6 species, namely Uca paradussumieri, Uca annulipes, Uca forcipata, Uca rosea, Uca crassipes and Uca tetragonon. The Shannon-Winner species diversity index $\left(\mathrm{H}^{\prime}\right)$ of fiddler crabs in $1^{\text {st }}$ and $2^{\text {nd }}$ lanes both are categorized medium, while in the $3^{\text {rd }}$ lane is categorized low. The range of values $H^{\prime}=0,3-1,5$. The value of species abundance index (Xi) ranges from 3-16.6 ind $/ \mathrm{m}^{2}$. The value of evenness index (e) ranges from 0,72 to 0,84. The dominance index value $(\mathrm{C})$ ranges from 0,3 to 0,5 categorized as the absence of the dominant species of fiddler crab. Comparison of species similarity index (IS) for each lane is categorized differently, for the $1^{\text {st }}$ and $2^{\text {nd }}$ lane the index is $91 \%$ and categorized as having high species similarity, then in $2^{\text {nd }}$ and $3^{\text {rd }}$ lane the index is $75 \%$ and categorized as having a medium species similarity, whereas the index for $1^{\text {st }}$ and $3^{\text {rd }}$ is $60 \%$, therefore it is categorized as having low species similarity.
\end{abstract}

Keyword: Diversity, Fiddler Crab, Karimunting Village

\section{PENDAHULUAN}

Kepiting biola merupakan fauna mangrove yang berperanan penting sebagai dekomposer kawasan mangrove (Hamidah dkk., 2014), aktivitas kepiting biola memberikan efek nyata bila hadir dalam populasi besar karena liang yang dibuatnya dapat menciptakan sirkulasi udara sehingga memungkinkan terjadi perombakan dalam sedimen. Perombakan ini dapat mencegah akumulasi mineral di bagian bawah sedimen sehingga kandungan unsur hara tetap stabil dan kesuburan sedimen untuk pertumbuhan vegetasi tetap terjaga (Murniati \& Pratiwi, 2015), selain itu kepiting biola merupakan pemakan detritus (detrivor) yang membantu dekomposisi pada mangrove, sehingga keberadaannya sangat penting dalam rantai makanan ekosistem mangrove. Mangrove merupakan habitat kepiting biola dan merupakan ekosistem yang kompleks, terdiri atas flora dan fauna daerah pantai dan hidup di antara batas air pasang dan surut. Ekosistem mangrove berperan dalam melindungi garis pantai dari erosi, gelombang laut dan angin topan, serta 
berperan sebagai buffer (perisai alam). Fungsi lain dari mangrove yaitu menstabilkan tanah dengan menangkap dan memerangkap endapan material dari darat yang terbawa air sungai kemudian mengalir ke tengah laut oleh arus (Saragi \& Desrita, 2018).

Kawasan mangrove Desa Karimunting membentang menghadap pantai yang didalamnya terdapat beberapa fauna mangrove satu diantaranya adalah kepiting biola (Uca spp.) yang termasuk dalam klasifikasi famili Ocypodidae. Kepiting biola di kawasan hutan mangrove Desa Karimunting perlu dilakukan pengamatan tentang keanekaragaman jenis, karena belum dilakukan penelitian tentang keanekaragaman kepiting biola pada lokasi tersebut, hal lain juga dapat memperkenalkan keberadaan kawasan mangrove Desa Karimunting dan potensi kepiting biola sehingga dapat bermanfaat bagi masyarakat Desa Karimunting.

Tujuan penelitian ini adalah untuk mengumpulkan data mengenai keanekaragaman kepiting biola di hutan mangrove Desa Karimunting Kecamatan Sungai Raya Kepulauan Kabupaten Bengkayang. Manfaat penelitian ini adalah memberikan informasi tentang keanekaragaman kepiting biola untuk pengelolaan kawasan Desa Karimunting, yaitu melalui sebaran keanekaragaman kepiting biola dari tepi laut ke arah darat yang terdapat di kawasan mangrove Desa Karimunting.

\section{METODE PENELITIAN}

Penelitian dilaksanakan di kawasan hutan mangrove Desa Karimunting Kecamatan Sungai Raya Kepulauan
Kabupaten Bengkayang, pada waktu 15 Oktober s/d 14 November 2019. Alat-alat yang digunakan dalam penelitian berupa peta lokasi penelitian, GPS (Global Position System), kamera, tally sheet,alat tulis, buku identifikasi, meteran/roll meter, tali rafia, mall 1x1 meter, soil tester, salt meter, sarung tangan, tongkat dengan panjang $150 \mathrm{~cm}$ dan berdiameter $3 \mathrm{~cm}$ dan lux meter, adapun bahan yang digunakan dalam penelitian yaitu Batu Es, Alkohol 70\% dan Air.

\section{Metode Pengumpulan Data}

Pengumpulan data yang digunakan dalam penelitian ini menggunakan metode survei, sedangkan pengambilan data kepiting biola menggunakan teknik sampling. penelitian ini menggunakan teknik purposive sampling, dibantu dengan jalur dan plot sebagai pengamatan objek penelitian.

Pembuatan jalur dilakukan dengan arah horizontal searah garis pantai, disesuaikan dengan kondisi lapangan berdasarkan lebar atau ketebalan vegetasi mangrove. Pengambilan data kepiting biola dilakukan pada setiap jalur, dimana peletakan jalur dibagi menjadi 3 jalur pengamatan. Jalur satu yaitu dekat laut batas pasang terendah yang sudah terdapat vegetasi mangrove dan terdapat kepiting biola. Jalur dua diletakan setelah jalur satu dan jalur tiga diletakan setelah jalur dua ketika menemukan kepiting biola. Panjang jalur adalah 500 meter, setiap jalur terdapat 10 plot yang berukuran 1x1 meter (Suprayogi, 2014).

Pengambilan sampel dilakukan sesuai dengan aktivitas kepiting biola mencari makan yaitu ketika surut. Hamidah $d k k$. (2014) mengatakan bahwa kepiting biola keluar dari sarang (liang) untuk mencari 
makan ketika surut pada substrat mangrove. Sampel kepiting biola diambil dengan cara menutup lubang bagian bawah kepiting biola dari samping ketika kepiting biola terlihat di dalam lubang dekat permukaan. Kepiting biola ditangkap menggunakan tangan disertai dengan tanah agar kepiting biola tidak mencapit dan tidak mengalami cacat (capit putus). Kepiting biola yang tertangkap, kemudian dimasukkan ke dalam plastik klip yang berisi es batu. Es batu digunakan, agar sampel yang diteliti melemah dan tidak mengalami kerusakan karena pergerakan yang liar setelah ditangkap, kepiting biola yang ditangkap kemudian dilakukan identifikasi.

Sampel dihitung dan dicatat berdasarkan jenis kelamin untuk setiap jalur, dengan memperhatikan warna, corak karapas kepiting biola dan capit besar apabila kepiting biola jantan, serta ukuran dan ciri lainnya dengan menggunakan buku pedoman identifikasi.

Penelitian yang dilakukan, juga mengambil data faktor lingkungan.
Pengambilan data faktor lingkungan dilakukan pada setiap jalur. Faktor lingkungan yang diukur adalah kelembapan tanah, suhu tanah, $\mathrm{pH}$ tanah, salinitas, tekstur tanah dan intensitas cahaya yang dilakukan pada waktu pagi, siang dan sore hari, kecuali data tektur tanah. Sampel tekstur tanah diambil di plot satu, plot lima dan plot sepeluh pada setiap jalur, kemudian dikompositkan. Hasil pengukuran setelah didapatkan dicatat ke dalam tally sheet.

\section{Analisis Data}

Data lapangan yang dimasukan di dalam tally sheet akan dilakukan analisis data berupa deskriptif kuantitatif, kemudian diperhitungkan. Tahap-tahap pengolahan data satwa liar dilakukan dengan menghitung indeks keanekaragaman jenis $\left(H^{\prime}\right)$, indeks kelimpahan jenis $(X i)$, indeks kemerataan jenis (e), indeks dominansi $(C)$ dan indeks kesamaan jenis (IS).

\section{HASIL DAN PEMBAHASAN}

Jenis-jenis kepiting biola di setiap jalur penelitian yang didapati terdapat 6 jenis dapat dilihat pada Tabel 1.

Tabel 1. Jenis Kepiting Biola yang Didapatkan pada Setiap Jalur Penelitian (Fiddler Crabs Species were Obtained at Each Research Line)

\begin{tabular}{|c|c|c|c|c|c|c|c|c|c|c|c|}
\hline \multirow{4}{*}{ No } & \multirow{4}{*}{ Spesies } & \multirow{4}{*}{$\begin{array}{c}\text { Ukuran } \\
\text { Karapas } \\
\text { (cm) }\end{array}$} & \multicolumn{6}{|c|}{ Jumlah individu } & & & \multirow{4}{*}{$\begin{array}{r}\text { Jumlah } \\
\text { Total }\end{array}$} \\
\hline & & & \multirow{2}{*}{\multicolumn{2}{|c|}{$\begin{array}{c}\text { Jalur } \\
1 \\
\text { Jenis } \\
\text { Kelamin }\end{array}$}} & \multirow{2}{*}{\multicolumn{2}{|c|}{$\begin{array}{c}\text { Jalur } \\
2 \\
\text { Jenis } \\
\text { Kelamin }\end{array}$}} & \multirow{2}{*}{\multicolumn{2}{|c|}{$\begin{array}{c}\text { Jalur } \\
3 \\
\text { Jenis } \\
\text { Kelamin }\end{array}$}} & \multicolumn{2}{|c|}{ Jumlah } & \\
\hline & & & & & & & & & \multicolumn{2}{|c|}{$\begin{array}{c}\text { Jenis } \\
\text { Kelamin }\end{array}$} & \\
\hline & & & $\mathbf{J}$ & B & $\mathbf{J}$ & B & $\mathbf{J}$ & B & $\mathbf{J}$ & B & \\
\hline 1 & Uca paradussumieri & 4 & 5 & 0 & 2 & 0 & 1 & 0 & 8 & 0 & 8 \\
\hline 2 & Uca crassipes & 1,4 & 10 & 8 & 3 & 1 & 0 & 0 & 13 & 9 & 22 \\
\hline 3 & Uca forcipata & 3 & 51 & 19 & 9 & 3 & 15 & 3 & 75 & 25 & 100 \\
\hline 4 & Uca rosea & 1,3 & 26 & 3 & 2 & 0 & 0 & 0 & 28 & 3 & 31 \\
\hline 5 & Uca annulipes & 1,6 & 7 & 3 & 0 & 0 & 0 & 0 & 7 & 3 & 10 \\
\hline 6 & Uca tetragonon & 3 & 23 & 11 & 4 & 7 & 3 & 8 & 30 & 26 & 56 \\
\hline \multicolumn{3}{|c|}{ Jumlah } & 122 & 44 & 20 & 11 & 19 & 11 & 161 & 66 & \multirow{3}{*}{227} \\
\hline \multicolumn{3}{|c|}{ Total } & \multicolumn{2}{|c|}{166} & \multicolumn{2}{|c|}{31} & \multicolumn{2}{|c|}{30} & \multirow{2}{*}{\multicolumn{2}{|c|}{227}} & \\
\hline \multicolumn{3}{|c|}{ Jumlah Jenis } & \multicolumn{2}{|c|}{6} & \multicolumn{2}{|c|}{5} & \multicolumn{2}{|c|}{3} & & & \\
\hline
\end{tabular}


Keterangan: J: Jantan, B: Betina, Ukuran karapas (cm): Ukuran yang paling lebar pada kerapas kepiting biola yang didapat di kawasan penelitian.

Rekapitulasi hasil pengamatan diketahui bahwa jenis-jenis kepiting biola yang didapatkan pada lokasi penelitian secara keseluruhan terdapat 6 jenis, yaitu Uca paradussumieri, Uca annulipes, Uca forcipata, Uca rosea, Uca crassipes dan Uca tetragonon (Tabel 1).

Uca forcipata adalah jenis kepiting biola yang paling banyak ditemukan pada jalur satu. Uca forcipata hidup pada substrat yang berlumpur hitam yaitu substrat yang terdapat banyak serasahserasah atau daun-daun tanaman bakau yang membusuk, sehingga membuat lumpur menjadi hitam dan berair. Hasan (2015) menyebutkan Uca forcipata hidup pada substrat berlumpur dekat perairan dan vegetasi, ditemukan di sekitar tepi perairan atau muara.

Jalur satu diletakan di depan mangrove langsung menghadap laut terdapat kondisi subtrat yang berlumpur, bervegetasi sedikit dan memotong dua anak sungai. Uca forcipata adalah jenis kepiting biola yang menempati habitat dekat dengan vegetasi mangrove yaitu keadaan yang terlindungi dari pemangsa seperti burung bangau dan ikan tembakol/glodok, selain itu memiliki karapas yang tidak mencolok dibandingkan dengan jenis lainnya sehingga salah satu sebab banyaknya jenis Uca forcipata. Jalur satu adalah jalur yang paling banyak didapatkan jumlah individu yaitu 166 individu dan jumlah jenis kepiting biola yang terdapat di jalur satu yaitu 6 jenis, hal ini disebabkan karena kepiting biola menyukai habitat yang terbuka. Jalur dua didapatkan 5 jenis kepiting biola dan 31 jumlah individu. Jalur tiga hanya terdapat 3 jenis kepiting biola dan 30 jumlah individu. Kepiting biola yang didapati pada jalur dua dan jalur tiga hanya terdapat pada plot satu dan plot delapan yaitu di tepian sungai kecil.

Semua jalur searah horizontal menghadap laut dengan kondisi setiap jalur memotong dua sungai kecil. Jalur dua dan tiga yang terdapat kepiting biola hanya pada daerah dekat sungai kecil yang terkena pasang surut air laut yaitu pada plot satu dan plot delapan, hal ini di sebabkan kepiting biola termasuk keluarga Ocypodidae yaitu salah satu famili kepiting yang memiliki habitat di daerah pasang surut (Hasan, 2015).

\section{Faktor Lingkungan}

Faktor lingkungan yang diukur yaitu kelembapan tanah, suhu tanah, $\mathrm{pH}$ tanah, salinitas air-tanah, intensitas cahaya dan tekstur tanah. 
Tabel 2. Faktor Lingkungan di Setiap Jalur Penelitian pada Waktu Pagi, Siang dan Sore Hari (Environmental Factors in Each Research Path at the Morning, Afternoon and Evening)

\begin{tabular}{clccccccccc}
\hline \multirow{2}{*}{ No Faktor lingkungan } & \multicolumn{3}{c}{ Jalur I } & \multicolumn{3}{c}{ Jalur II } & \multicolumn{3}{c}{ Jalur III } \\
\cline { 2 - 10 } & Pg & Sg & Sr & Pg & Sg & Sr & Pg & Sg & Sr \\
\hline 1 & Kelembapan tanah(\%) & 80 & 80 & 80 & 70 & 70 & 70 & 70 & 70 & 70 \\
2 & Suhu tanah $\left({ }^{\circ} \mathrm{C}\right)$ & 26 & 28 & 28 & 27 & 27 & 28 & 28 & 26 & 28 \\
3 & pH tanah & 5,5 & 6,0 & 6,0 & 5,0 & 5,0 & 5,0 & 5,5 & 5,5 & 5,5 \\
4 & Salinitasair-tanah(\%) & 44 & 35 & 16 & 43 & 34 & 18 & 23 & 17 & 11 \\
5 & Intensitas cahaya(Lux) & 1135 & 1385 & 602 & 1852 & 1852 & 295 & 1385 & 1135 & 144 \\
\hline
\end{tabular}

Keterangan: Data yang diambil waktu pagi (Pg) sekitar jam 8.30-10.50 WIBA, dalam keadaan cuaca cerah, data pada waktu siang (Sg) sekitar jam 12.45-14.24 WIBA, dalam keadaan cuaca cerah pada dan data yang diambil pada waktu sore (Sr) sekitar jam 16.38-17.45 WIBA.

Suhu tanah berperan penting dalam kehadiran kepiting biola, Murniati \& Pratiwi (2015) menyebutkan suhu yang terlalu tinggi dan terlalu rendah menyebabkan terhambatnya aktivitas kepiting biola baik di dalam liang maupun diluar liang. Kepiting biola merupakan hewan yang beradaptasi dengan baik pada lingkungan hangat terutama pada wilayah hujan tropis yang memiliki kisaran suhu $27^{\circ} \mathrm{C}-32^{\circ} \mathrm{C}$. Menurut Natania $d k k$. (2017) suhu yang sesuai untuk kehidupan kepiting biola adalah $18^{\circ} \mathrm{C}-35^{\circ} \mathrm{C}$ dan suhu ideal adalah $25^{\circ} \mathrm{C}-30^{\circ} \mathrm{C}$. Pengukuran suhu tanah di lokasi penelitian menunjukan bahwa pada lokasi tersebut terdapat suhu tanah yang ideal untuk kehidupan kepiting biola.

Pengukuran $\mathrm{pH}$ tanah pada waktu pagi, siang dan sore hari adalah sama di jalur dua dan jalur tiga, yaitu pada jalur dua 5,0 sedangkan jalur tiga 5,5. Hasil pengukuran $\mathrm{pH}$ tanah di jalur satu pada waktu siang dan sore hari adalah 6,0 dan pada pagi hari $\mathrm{pH}$ tanah yaitu 5,5. Menurut Hardjowigeno (1995) kriteria penilaian $\mathrm{pH}$ tanah dikategorikan masam pada kisaran $\mathrm{pH}$ 4,5-5,5 adapun kisaran
$\mathrm{pH}$ 5,6-6,5 dikategorikan agak masam. Jalur satu $\mathrm{pH}$ tanah pada waktu pagi dikategorikan masam, sedangkan pada waktu siang dan sore hari dikategorikan agak masam, sedang jalur dua dan tiga dikategorikan masam. Tanah yang masam pada lokasi penelitian disebabkan oleh crustaacea yang membuat lubang dengan menggali tanah bawah ke permukaan, karena tanah yang digali kepermukaan terkadang banyak mengandung sulfida yang teroksidasi menjadi sulfat (Hardjowigeno, 1995). Crustacea yang terdapat di jalur dua dan jalur tiga didominasi oleh jenis Episesarma (kepiting panjat) sehingga jenis Uca (kepiting biola) tidak ada kecuali pada tepian sungai kecil.

Tanah yang dikategorikan masam sangat baik untuk kehidupan kepiting biola disebabkan melimpahnya sumber makanan pada kondisi habitat dengan $\mathrm{pH}$ yang masam. Murniati \& Pratiwi (2015) menyebutkan jenis makanan kepiting biola salah satunya adalah bakteri dan materi organik lain yang terdapat di habitatnya. Menurut Hardjowigeno (1995), bahwa bakteri berkembang 
dengan baik pada $\mathrm{pH}$ 5,5 atau lebih, hal ini salah satu sebab populasi kepiting biola pada jalur satu lebih banyak dari jalur dua dan tiga karena kisaran $\mathrm{pH}$ jalur satu 5,5-6,0.

$$
\text { Murniati \& Pratiwi }
$$
menyebutkan salinitas merupakan faktor yang sangat penting untuk kehidupan kepiting biola. Salinitas menentukan penyebaran, pertumbuhan, jumlah larva yang bertahan hidup dan populasi kepiting biola. Salinitas kisaran 20\%030\% merupakan habitat pertumbuhan kepiting biola. Salinitas air-tanah di jalur satu berkisar antara 16\%-44\%o, jalur dua hasil pengukuran salinitas berkisar antara 18\%o-34\%o, sedangkan pada jalur tiga berkisar antara 11\%o-23\%o. Salinitas airtanah tertinggi ditemukan pada jalur satu karena menghadap laut langsung, sedangkan salinitas terendah terdapat pada jalur tiga karena daerah tersebut jarang terkena air laut ketika pasang kecuali di dekat sungai pada plot satu dan plot delapan. Waktu pagi adalah waktu dimana ukuran salinitas dikatakan tinggi dibandingkan pada waktu lainnya disebabkan waktu surut pertama terjadi pada waktu pagi.

Odum (1996) menyebutkan intensitas cahaya mempengaruhi pola penyebaran organisme. Ada sebagian organisme yang menyukai intensitas cahaya yang besar, namun ada juga organisme yang lebih menyukai cahaya yang redup. Hasil pengukuran intensitas cahaya yang dilakukan pada setiap jalur penelitian berkisar antara 144-1852 Lux. Berdasarkan hasil pengukuran di lapangan memperlihatkan kisaran intensitas cahaya yang tidak terlalu besar. Pengukuran kelembapan tanah yang dilakukan pada setiap jalur penelitian adalah sama berkisar antara 70\%-80\%, karena lokasi penelitian di daerah intertidal dan dilakukan pada musim penghujan sehingga persentase kelembapan tanah tinggi. Lokasi penelitian termasuk jenis tanah alluvial, tanah alluvial adalah jenis tanah didominasi oleh fraksi debu yang memiliki pori-pori halus (micro pore), sehingga kuat dalam menahan air laut. Kelembapan tanah dipengaruhi oleh tinggi air tanah. Air tanah yang tinggi menyebabkan persentase kelembapan tanah menjadi tinggi, hal ini juga berpengaruh pada kehidupan kepiting biola. Kepiting biola menggunakan alat pernafasan insang, ketika pada waktu surut insang kepiting biola termodifikasi menjadi seperti paru-paru. Pernapasan yang termodifikasi hanya bertahan dalam waktu sebentar, sehingga memerlukan air tanah untuk bernafas.

Lokasi penelitian didominansi oleh fraksi debu, sifat fraksi debu mengikat antara partikel-partikelnya, sehingga menyebabkan tanah pada lokasi penelitian bersubtrat padat. Kepiting biola lebih menyukai habitat pada subtrat yang padat karena memberikan kontruksi yang lebih kuat dan aman untuk pembuatan lubang (Murniati \& Pratiwi 2015). Hasil pengukuran tekstur tanah di Laboratorium Kimia dan Kesuburan Tanah Fakultas Pertanian Universitas Tanjungpura dapat dilihat pada Tabel 3. 
Tabel 3. Tekstur Tanah di Setiap Jalur Penelitian (Soil Texture in Each Research Path)

\section{$\begin{array}{cccc}\text { No } & \text { Faktor } & \text { Jalur } 1 & \text { Jalur } 2\end{array}$}

\begin{tabular}{lllll}
\hline 1 & Tekstur tanah (\%) & Lempung berdebu & Debu & Lempung berdebu \\
\hline
\end{tabular}

Keterangan: Tanah yang dijadikan sampel adalah tanah komposit yang diambil di plot satu, plot lima dan plot sepuluh pada setiap jalur yaitu jalur satu, jalur dua dan jalur tiga.

Kepiting biola hidup didalam liang pada habitat mangrove yang sangat berpengaruh pada kondisi subtrat (Murniati \& Pratiwi, 2015). Hasil pengujian yang dilakukan di Laboratorium menunjukan persentase tekstur dari fraksi tanah halus $(<2$ $\mathrm{mm})$ yaitu pasir, debu dan liat pada setiap jalur hampir sama. Sampel yang diuji pada setiap jalur diambil dari tanah pada plot satu, plot lima dan plot sepuluh. Persentase fraksi tanah jalur satu terdapat pada plot satu, plot lima dan plot sepuluh yang dikompositkan yaitu pasir $0,00 \%$, debu $82,80 \%$ dan liat $17,20 \%$ sehingga diklasifikasikan menjadi tekstur lempung berdebu. Jalur dua terdapat persentase fraksi pasir $0,24 \%$, debu $88,56 \%$ dan liat 11,20 diklasifikasikan menjadi tekstur debu, sedangkan pada jalur tiga fraksi pasir $1,20 \%$, debu $85,60 \%$ dan liat $13,20 \%$ diklasifikasikan menjadi tekstur lempung berdebu. Berdasarkan kasar halusnya tanah pada lokasi penelitian dikelompokan sebagai kelas tekstur sedang.

Hasil rata-rata faktor lingkungan pada waktu pagi, siang dan sore hari di setiap jalur bahwa di jalur satu hasil rata-rata kelembapan tanah $73,3 \%$, rata-rata suhu tanah pada $27,3^{\circ} \mathrm{C}, \mathrm{pH}$ tanah 5,83, salinitas air-tanah 31,6 ppt dan Intensitas cahaya pada jalur satu 1.040 Lux. Jalur dua hasil rata-rata kelembapan tanah $73,3 \%$, rata-rata suhu tanah pada $27,3^{\circ} \mathrm{C}, \mathrm{pH}$ tanah 5 , salinitas air-tanah 31,6 ppt dan intensitas cahaya 1.333 Lux. Jalur tiga hasil rata-rata kelembapan tanah $73,3 \%$, rata-rata suhu tanah $27,3^{\circ} \mathrm{C}, \mathrm{pH}$ tanah 5,5 , salinitas airtanah 18,6 ppt dan intensitas cahaya 888 . Hasil dari rata-rata faktor lingkungan di lokasi penelitian bahwa dapat dikatakan sesuai dengan habitat dari jenis kepiting biola.

\section{Indeks Keanekaragaman Jenis}

Keanekaragaman jenis kepiting biola mengacu pada kriteria Shannon-Winner dikategorikan rendah yaitu pada jalur tiga, sedangkan pada jalur satu dan jalur dua dikategorikan sedang (Tabel 4). Keanekaragaman jenis dipengaruhi oleh berbagai faktor, diantaranya jenis habitat tempat hidup, stabilitas lingkungan, produktifitas, kompetisi dan penyangga rantai makanan, semakin baik kondisi habitat maka nilai indeks keanekaragaman jenis biota akan semakin tinggi, begitu juga sebaliknya. Indeks keanekaragaman jenis akan menurun jika menurunnya kualitas habitat (Ulum $d k k$., 2012). Rendahnya indeks keanekaragaman di lokasi penelitian disebabkan distribusi atau sebaran jenis kepiting biola pada lokasi penelitian hanya terdapat jumlah jenis kepiting biola yang sedikit. Proses sebaran kepiting biola terutama pada vase larva sangat dipengaruhi oleh faktor ekologi dan batas geografis. 
Tabel 4. Indeks Kekaragaman Jenis Kepiting Biola di Desa Karimunting Kecamatan Sungai Raya Kepuluan Kabupaten Bengkayang (The diversity index of fiddler crabs in Karimunting Village Sungai Raya Kepuluan District, Bengkayang Regency)

\begin{tabular}{lccc}
\hline Jalur & $\mathbf{1}$ & $\mathbf{2}$ & $\mathbf{3}$ \\
\hline Nilai $(\bar{H})$ & 1,5 & 1,4 & 0,3 \\
Kriteria & Sedang & Sedang & Rendah \\
\hline
\end{tabular}

Faktor lingkungan pada lokasi penelitian dapat dikatakan sesuai untuk habitat kepiting biola akan tetapi tidak adanya indeks keanekaragaman yang tinggi pada setiap jalur, hal ini menunjukan bahwa rendahnya nilai indeks keanekaragaman jenis kepiting biola bukan disebabkan oleh faktor lingkungan yang diukur. Nilai $H^{\prime}$ pada jalur satu dan jalur dua lebih tinggi dibandingkan jalur tiga, dapat disebabkan rata-rata salinitas air-tanah pada jalur satu dan dua lebih tinggi dibandingkan pada jalur tiga, hal ini terjadi dikarenakan pada kawasan jalur tiga jarang terkena air laut ketika pasang kecuali di dekat sungai pada plot satu dan plot delapan. Jalur satu adalah jalur dengan nilai $H^{\prime}$ paling tinggi dikarenakan jalur satu diletakan pada kawasan menghadap laut langsung yang terkena pasang surut air laut. Waktu pagi adalah waktu dimana ukuran salinitas dikatakan tinggi dibandingkan pada waktu lainnya disebabkan waktu surut pertama terjadi pada waktu pagi. Ratarata salinitas jalur satu dan dua yaitu 31,6 ppt mendekati kisaran salinitas yang sesuai dengan habitat kepiting biola yaitu salinitas yang optimum bagi crustaceae berkisar antara 23-26 ppt (Hamidah $d k k$., 2014).
Faktor lain yang mempengaruhi nilai indeks keanekaragaman yaitu intensitas cahaya diketahui nilai rata-rata pengukuran dari waktu yang berbeda pada jalur satu yaitu 1.040 Lux, jalur dua yaitu 1.333 Lux, sedangkan rata-rata intensitas cahaya jalur tiga yaitu 888 . Jalur satu dan jalur dua memiliki intensitas cahaya yang tinggi dibanding jalur tiga dikarenakan pada jalur satu di letakan pada kawasan yang sedikit vegetasi, jalur dua tutupan vegetasi juga tidak terlalu rapat, sedangkan pada jalur tiga tutupan vegetasi terlihat rapat dibanding dengan jalur satu dan dua, hal ini dapat disimpulkan bahwa kepiting biola menyukai keadaan intensitas cahaya yang tinggi dengan vegetasi terbuka.

\section{Indeks Kelimpahan Jenis}

Indeks kelimpahan jenis (Xi) menunjukan perbandingan banyaknya satu spesies terhadap jumlah seluruh spesies (Naidu \& Kumar, 2016). Indeks kelimpahan jenis merupakan jumlah dari setiap hasil perbandingan antara luas areal penelitian dengan jumlah individu suatu jenis. Mengetahui nilai $X i$ untuk dilakukan pembandingan nilai antar setiap jalur tanpa terdapat kriteria. 
Tabel 5. Indeks Kelimpahan Jenis Kepiting Biola di Lokasi Penelitian (The Index Of Abundance Of Fiddler Crabs In The Research Location)

\begin{tabular}{|c|c|c|c|c|c|c|c|c|}
\hline \multirow[b]{2}{*}{ No } & \multirow[b]{2}{*}{ Nama Jenis } & \multirow[b]{2}{*}{$\begin{array}{c}\mathrm{A} \\
\left(\mathrm{m}^{2}\right)\end{array}$} & \multicolumn{2}{|c|}{ Jalur 1} & \multicolumn{2}{|c|}{ Jalur 2} & \multicolumn{2}{|c|}{ Jalur 3} \\
\hline & & & $n$ & $\begin{array}{l}X \boldsymbol{X}=\boldsymbol{n i} / \mathbf{A} \\
\left(\mathrm{ind} / \mathrm{m}^{2}\right)\end{array}$ & $N$ & $\begin{array}{l}\boldsymbol{X i}=\boldsymbol{n i} / \mathbf{A} \\
\left(\mathrm{ind} / \mathrm{m}^{2}\right)\end{array}$ & $n$ & $\begin{array}{l}X \boldsymbol{X}=\boldsymbol{n i} / \mathbf{A} \\
\left(\mathrm{ind} / \mathrm{m}^{2}\right)\end{array}$ \\
\hline 1 & Uca paradussumieri & 10 & 5 & 0,5 & 2 & 0,2 & 1 & 0,1 \\
\hline 2 & Uca crassipes & 10 & 18 & 1,8 & 4 & 0,4 & - & - \\
\hline 3 & Uca forcipata & 10 & 70 & 7 & 12 & 1,2 & 18 & 1,8 \\
\hline 4 & Uca rosea & 10 & 29 & 2,9 & 2 & 0,2 & - & - \\
\hline 5 & Uca annulipes & 10 & 10 & 1 & - & - & - & - \\
\hline \multirow[t]{3}{*}{6} & Uca tetragonon & 10 & 34 & 3,4 & 11 & 1,1 & 11 & 1,1 \\
\hline & Jumlah Total & & 166 & 16,6 & 31 & 3,1 & 30 & 3 \\
\hline & Jumlah Spesies & & & 6 & & 5 & & 3 \\
\hline
\end{tabular}

Keterangan: A: Luas areal, $n$ : Jumlah individu, Xi: Kelimpahan jenis

Indeks Kelimpahan jenis kepiting biola (Tabel 5) menunjukan bahwa pada jalur satu ditemukan enam jenis kepiting biola dengan jumlah keseluruhan 166 individu. Jenis-jenis kepiting bioala yang ditemukan yaitu Uca paradussumieri, Uca crassipes, Uca forcipata, Uca rosea, Uca annulipes dan Uca tetragonon. Jumlah indeks kelimpahan jenis kepiting biola keseluruhan yang ditemukan pada jalur satu yaitu 16,6 $\mathrm{ind} / \mathrm{m}^{2}$, Indeks kelimpahan jenis yang paling tinggi adalah jenis Uca forcipata yaitu $7 \mathrm{ind} / \mathrm{m}^{2}$ sedangkan indeks kelimpahan yang paling rendah yaitu Uca paradussumieri $X i=0,5 \mathrm{ind} / \mathrm{m}^{2}$.

Jalur dua indek kelimpahan jenis bahwa ditemukan lima jenis kepiting biola dengan jumlah keseluruhan 31 individu. Jenis-jenis kepiting biola yang ditemukan yaitu Uca paradussumieri, Uca crassipes, Uca forcipata, Uca rosea dan Uca annulipes. Jumlah indeks kelimpahan jenis kepiting biola keseluruhan yang ditemukan pada jalur dua yaitu $3,1 \mathrm{ind} / \mathrm{m}^{2}$. Indeks kelimpahan jenis yang paling tinggi adalah jenis $U c a$ forcipata yaitu $1,2 \mathrm{ind} / \mathrm{m}^{2}$,sedangkan indeks kelimpahan yang paling rendah yaitu Uca paradussumieri dengan nilai $0,2 \mathrm{ind} / \mathrm{m}^{2}$.

Hasil analis indeks kelimpahan keseluruhan jenis kepiting pada jalur tiga yaitu $3 \mathrm{ind} / \mathrm{m}^{2}$ dengan jumlah individu keseluruhan yang didapat 30 individu. Jenis-jenis kepiting biola yang ditemukan pada jalur adalah Uca paradussumieri, Uca forcipata dan Uca tetragonon. Indeks kelimpahan jenis yang paling tinggi adalah jenis Uca forcipata yaitu $1,8 \mathrm{ind} / \mathrm{m}^{2}$, sedangkan indeks kelimpahan yang paling rendah yaitu Uca paradussumieri dengan nilai $0,1 \mathrm{ind} / \mathrm{m}^{2}$.

Ketiga jalur memiliki nilai indeks kelimpahan jenis yang paling tinggi adalah jenis Uca forcipata, sedangkan yang paling rendah adalah jenis Uca paradussumieri. Kelimpahan suatu jenis dalam kawasan tertentu dapat dipengaruhi oleh faktor lingkungan dan prilaku kepiting biola. Uca paradussumieri adalah jenis kepiting dengan nilai kelimpahan jenis paling 
rendah disebabkan prilaku jenis $U c a$ paradussumieri menempati kawasan yang tebuka sehingga pemangsa mudah untuk memangsanya.

Jalur satu memiliki nilai Indeks kelimpahan yang paling tinggi diantara ketiga jalur penelitian, disebabkan pada jalur satu adalah lokasi dimana diletakan di posisi paling depan. Kondisi paling depan adalah sangat sesuai dengan habitat kepiting biola, terlebih jalur satu adalah jalur yang sering terkena pasang surut.

Nilai indeks kelimpahan jenis $(X i)$ yang paling tinggi adalah jenis Uca forcipata, sedangkan yang paling rendah adalah jenis Uca paradussumieri. Kelimpahan suatu jenis dalam kawasan tertentu dapat dipengaruhi oleh faktor lingkungan dan prilaku kepiting biola. Uca paradussumieri adalah jenis kepiting dengan nilai kelimpahan jenis paling rendah disebabkan prilaku jenis $U c a$

paradussumieri menempati kawasan yang tebuka sehingga pemangsa mudah untuk memangsanya.

Jalur satu memiliki nilai Indeks kelimpahan yang paling tinggi diantara ketiga jalur penelitian, disebabkan pada jalur satu adalah lokasi dimana diletakan di posisi paling depan. Kondisi paling depan adalah sangat sesuai dengan habitat kepiting biola, terlebih jalur satu adalah jalur yang sering terkena pasang surut. Kepiting biola termasuk keluarga Ocypodidae yaitu salah satu famili kepiting yang memiliki habitat di daerah pasang surut (Hasan, 2015).

\section{Indeks Kemerataan Jenis}

Indeks kemerataan jenis yang disebut juga indeks Pielou. Indeks kemerataan ini merupakan tingkat kesamaan jumlah spesies satu terdapat spesies yang lainnya (Naidu \& Kumar, 2016).

Tabel 6. Indeks Kemeretaan Jenis Kepitng Biola di Lokasi Penelitian (The Index Value Of Species Evenness In The Research Location)

\begin{tabular}{lccc}
\hline Jalur & $\mathbf{1}$ & $\mathbf{2}$ & $\mathbf{3}$ \\
\hline Nilai $(e)$ & 0,84 & 0,84 & 0,72 \\
Kriteria & Tinggi & Tinggi & Sedang \\
\hline
\end{tabular}

Hasil perhitungan indeks kemeratan jenis (e) (Tabel 6) menunjukan bahwa nilai indeks kemeratan jenis jalur satu dan jalur dua yaitu $e=0,84$, sedangkan nilai indeks kelimpahan jenis pada jalur tiga $e=0,72$. Odum dalam Nento $d k k$. (2013) mengkategorikan jika nilai kemerataan $\geq 0,75$ maka diartikan penyebaran jenis merata, jika nilai kemerataan $\geq 0,50$ sampai mendekati $\leq 0,75$, maka penyebaran jenis diartikan cukup merata, sedangkan jika nilai kemerataan $\leq 0,50$, maka penyebaran jenis diartikan tidak merata, sehingga kategori jalur satu dan dua dilihat dari analisis data dapat dikatakan memiliki indeks kemerataan jenis yang tinggi, sedangkan pada jalur tiga indeks kemerataan jenis dikategorikan sedang. Penyebaran hewan didasarkan atas faktor makanan dan kompetisi antar spesies atau hewan lain yang memakan 
sumber makanan yang sama, hal ini menyebabkan kecenderungan kepiting biola akan tinggal di suatu kawasan karena melimpahnya sumber makanan. Kareho dkk. (2019) menyebutkan bahwa kepiting biola adalah konsumen serasah daun mangrove dan bakteri yang berada berada di kawasan mangrove. Lokasi penelitian memiliki $\mathrm{pH}$ tanah yang dikategorikan asam sehingga bakteri melimpah pada keadaan tersebut,
Hardjowigeno (1995) menyebutkan bahwa bakteri berkembang dengan baik pada $\mathrm{pH}$ 5,5.

\section{Indeks Dominansi}

Indeks dominansi (C) digunakan untuk memperoleh informasi mengenai spesies yang mendominasi pada suatu populasi. Dominansi spesies tertentu diketahui dengan indeks dominansi Simpons Odum (1996).

Tabel 7. Indeks Dominansi Jenis Kepitng Biola di Lokasi Penelitian (The Index Dominance of species Fiddler Crabs Species in the Research Locations)

\begin{tabular}{lccc}
\hline Jalur & $\mathbf{1}$ & $\mathbf{2}$ & $\mathbf{3}$ \\
\hline Nilai $(C)$ & 0,3 & 0,3 & 0,5 \\
\multirow{2}{*}{ Kriteria } & $\begin{array}{l}\text { Tidak ada yang } \\
\text { mendominansi }\end{array}$ & $\begin{array}{l}\text { Tidak ada yang } \\
\text { mendominansi }\end{array}$ & $\begin{array}{l}\text { Tidak ada yang } \\
\text { mendominansi }\end{array}$ \\
\hline
\end{tabular}

Berdasarkan hasil analisis nilai indeks dominansi (Tabel 7), dapat dilihat bahwa pada jalur tiga nilai $C=0,5$, sehingga dikategorikan memiliki indeks dominansi rendah, sedangkan pada jalur satu dan jalur dua nilai $C=0,3$, sehingga dikategorikan memiliki dominansi yang rendah atau tidak ada yang jenis kepiting biola yang mendominasi. Jalur tiga juga dapat dikatakan memiliki nilai indeks dominansi yang sedang. Menurut Odum dalam Nento $d k k$. (2013) indeks dominansi dengan nilai $\leq 0,50$ berarti hampir tidak ada spesies yang mendominasi sehingga dikategorikan rendah, nilai indeks dominansi $\geq 0,50$ $\leq 0,75$ yaitu indeks dominansi dikategorikan sedang dan $\geq 0,75$ sampai mendekati 1 dikategorikan memiliki indeks dominansi tinggi.

Indeks dominansi merupakan pola dominansi suatu spesies lainnya dalam komunitas suatu ekosistem (Mawazin et al., 2013). Natania $d k k$. (2017) menambahkan bahwa semakin tinggi nilai indeks dominansi suatu spesies pada suatu lokasi penelitian menggambarkan pola penguasaan terpusat pada spesies-spesies tertentu atau komunitas tertentu lebih dikuasai oleh spesies tertentu, sebaliknya jika nilai indeks dominansi semakin rendah maka akan menggambarkan pola penguasaan spesies dalam komunitas tersebut relatif menyebar pada masingmasing spesies. Indeks dominansi dikategorikan tinggi apabila dominansi hanya tertuju pada satu spesies, tetapi jika nilai indeks dominansi dikategorikan rendah maka dominansi tertuju pada beberapa spesies (Natania $d k k$., 2017). Semua jalur di lokasi penelitian tidak ada jenis kepiting biola yang mendominasi dikarenakan sebaran 
jumlah jenis kepiting dilokasi penelitian mendekati sama. Sebaran jenis kepiting biola yang sama disebabkan habitat semua jenis kepiting biola yang didapati sesuai dengan lokasi penelitian, seperti $\mathrm{pH}$ tanah ketiga jalur penelitian yaitu diketahui masam yang menyebabkan sumber makanan kepiting biola melimpah. Faktor lingkungan yang diukur di setiap lokasi penelitian adalah sesuai dengan kisaran ukuran untuk habitat kepiting biola, sehingga tidak ada jenis kepiting biola yang mendominansi.

Indeks Kesamaan Jenis

Tabel 8. Nilai Indeks Kesamaan Jenis (IS) di Lokasi Penelitian (The Index Value of Species Similarity (IS) in the Research Location)

\begin{tabular}{ccccc}
\hline \multirow{2}{*}{ No } & \multirow{2}{*}{ Indeks } & \multicolumn{3}{c}{ Nilai } \\
\cline { 3 - 5 } & & $\begin{array}{c}\text { Jalur } \\
\mathbf{1} \text { dan 2 }\end{array}$ & $\begin{array}{c}\text { Jalur } \\
\mathbf{2} \text { dan 3 }\end{array}$ & $\begin{array}{c}\text { Jalur } \\
\mathbf{1} \text { dan 3 }\end{array}$ \\
\hline 1 & Kesamaan Jenis $(I S)$ & 91 & 75 & 60 \\
\hline
\end{tabular}

Kesamaan komunitas sangat dipengaruhi oleh jumlah jenis dan jenisjenis yang hidup dikedua lokasi. Semakin banyak jenis yang sama dikedua lokasi maka akan semakin besar pula indeks kesamaan jenis. Jalur satu dan jalur dua dikategorikan memiliki indeks kesamaan jenis tinggi disebabkan diantara kedua jalur terdapat lima jenis kepiting biola yang sama, sedangkan perbandingan antara jalur satu dan jalur tiga dikategorikan memiliki indeks kesamaan yang rendah.

Rendahnya indeks kesamaan jenis pada jalur satu dan jalur tiga disebabkan perbandingan jumlah jenis pada jalur tersebut berbeda jauh dan hanya terdapat tiga jenis kepiting biola yang sama. Faktor yang dapat menyebabkan
Hasil analisis indeks kesamaan jenis kepiting biola di lokasi penelitian (Tabel 8) dapat diketahui bahwa pada jalur satu dan dua nilai $I S=91 \%$ dikategorikan memiliki indeks kesamaan jenis tinggi. Perbandingan kesaman jenis pada jalur dua dan jalur tiga dikategorikan sedang karena nilai $I S=75 \%$ sedangkan pada jalur satu dan tiga nilai $I S=60 \%$, sehingga dikategorikan rendah, hal ini sesuai dengan kriteria indeks kesamaan jenis Sorensen. Kriteria Sorensen (Odum, 1996) yaitu nilai IS <40\%: Sangat rendah, $I S=41-60 \%$ : Rendah, $I S=61-80 \%$ : sedang, $I S=81-100 \%$ : Sangat tinggi. 
vegetasi yang berbeda dengan karakteristik anatomi dan morfologi daun yang berbeda pada jalur satu dan jalur tiga. Perbedaan karakteristik anatomi dan morfologi pada daun Avicennia dan Rhizophora menyebabkan perbedaan laju dekomposisi. Hasil penelitian Hardianto dkk. (2015) diketahui bahwa Avicenniasp. memiliki laju dekomposisi lebih besar yaitu $0,30 \mathrm{~g}$ /hari dibandingkan dengan dekomposisi jenis Rhizophorasp. sebesar $0,13 \mathrm{~g} /$ hari, hal ini dapat dikatakan bahwa rendahnya indeks kesamaan jenis pada jalur satu dan jalur tiga dipengaruhi dari morfologi dan anatomi dari daun kedua

\section{KESIMPULAN}

Berdasarkan hasil penelitian dapat disimpulkan bahwa jenis kepiting biola yang didapatkan di mangrove Desa Karimunting Kecamatan Sungai Raya Kepulauan Kabupaten Bengkayang sebanyak 6 jenis yaitu Ucaparadussumieri, Uca forcipata, Uca crassipes, Uca annulipes, Uca rosea dan Uca tetragonon.

Komposisi jenis kepiting biola di lokasi penelitian yaitu nilai indeks keanekaragaman jenis $\left(H^{\prime}\right)$ berkisar antara 0,3-16,6, yaitu pada jalur tiga dikategorikan rendah, sedangkan pada jalur satu dan jalur dua diaktegorikan sedang, hal ini dipengaruhi oleh intensitas cahaya dan salinitas air-tanah. Nilai indeks kelimpahan jenis $(X i)$ berkisar antara 3-16,6 ind $/ \mathrm{m}^{2}$, nilai indeks kemerataan jenis $(e)$ berkisar antara $0,72-$ 0,84 , nilai indeks dominansi $(C)$ berkisar anatara 0,3-05, sedangkanperbandingan indeks kesamaan jenis (IS) setiap jalur dikategorikan berbeda-beda, pada jalur vegetasi yang berbeda antara kedua jalur, menyebabkan sumber makan yang tersedia bagi kepiting biola berbeda antara jalur satu dan jalur tiga.

Faktor lain yang menyebabkan nilai indeks kesamaan jenis pada jalur satu dan jalur tiga dikategorikan rendah, yaitu sebab habitat dari kepiting biola itu sendiri. Kepiting biola yang didapati kebanyakan kepiting biola yang menempati kawasan yang terbuka di dekat muara. Kawasan muara adalah kawasan terletak pada jalur satu sehingga terlihat jelas spesies pada jalur satu tidak sama banyaknya dengan jalur tiga.

satu dan dua $I S=91 \%$ kategori tinggi, jalur dua dan tiga $I S=75 \%$ dikategorikan sedang dan jalur satu dan tiga $I S=60 \%$ dikategorikan rendah.

Nilai rata-rata pengukuran faktor lingkungan yang diukur mendekati sama kecuali pada salinitas air-tanah dan intensitas cahaya, disebabkan pada jalur satu dan dua nilai dari kedua pengukuran mendekati sama sedangkan pada jalur tiga sangat berbeda. Salinitas air-tanah dan intensitas cahaya yang diukur memberikan pengaruh terhadap komposisi jenis kepiting biola.

\section{SARAN}

1. Perlu dilakukan kebijakan dalam pemeliharaan mangrove di Desa Karimunting Kecamatansungai raya kepulauan Kabupaten Bengkayang sehingga dapat dijadikan tempat ekowisata, sehingga jenis-jenis kepiting biola dan kawasan mangrove Desa Karimunting terekspos. 
2. Perlu dilakukan penelitian lanjutan mengenai fauna lainya di mangrove Desa Karimunting.

\section{UCAPAN TERIMAKASI}

Penulis mengucapkan terimakasih kepada Kepala Desa Karimunting yang telah memberikan ijin untuk melakukan penelitian di Desa Karimunting Kecamatan Sungai Raya Kepulauan Kabupaten Bengkayang. Semoga artikel ini bermanfaat bagi banyak pihak terutama dalam pengelolaan mangrove Desa Karimunting.

\section{DAFTAR PUSTAKA}

Ghufran HK, 2012. Ekosistem Mangrove: Potensi, Fungsi dan Pengelolaan. Jakarta: Rineka Cipta.

Hamidah A, Fratiwi M, Siburia J. 2014. Kepadatan Kepiting Biola (Kepiting Biola Spp.) Jantan Dan Betina di Desa Tungkal I Tanjung Jabung Barat. Jurnal Penelitian Universitas Jambi Seri Sains. 16 (2): 43-50.

Hardianto, Karmila, Yulma. 2015. Produktivitas dan Laju Dekomposisi Serasah Mangrove di Kawasan Konservasi Mangrove Dan Bekantan (Kkmb)Kota Tarakan Kalimantan Utara. Jurna Horpodon Borneo, 8(1) 43-50.

Hardjowigeno S. 1995. Ilmu Tanah. Jakarta: Akademika Pressindo.

Hasan R. 2015. Populasi dan Mikrohabitat Kepiting Genus Kepiting Biola di Kawasan Konservasi Mangrove Pantai Panjang Bengkulu. Biologi, Sains, Lingkungan, dan Pembelajarannya: 676-681.

Iskandar J. 2015. Keanekaragaman Hayati Jenis Binatang; Manfaat
Ekologi Bagi Manusia. Yogyakarta: Graha Ilmu.

Kareho BAM, Masithah DE, Tjahjaningsih W. 2019. Bacterial Composition in the Gastrointestinal Tract of $U_{c a}$ spp Crabs Fed on Avicennia marinaLeaf Litter. International Conference on Fisheries and Marine Science, IOP Conf. Series: Earth and Environmental Science 236 (2019) 012080.

Murniati DC, Pratiwi R. 2015. Kepiting Kepiting Biola di Mangrove Indonesia. Tinjauan Aspek Biologi dan Ekologi Untuk Eksplorasi. Jakarta: Lipi Press (Inpress).

Naidu MT, Kumar OA. 2016. Tree Diversity, Stand Structure And Community Composition Of Tropical Forests In Eastern Ghats Of Andhra Peadesh, India. Journal of Asia-Pacific Biodiversity.

Natania T, Herliany EN,Kusuma BA. 2017.Struktur Komunitas Kepiting Biola (Kepiting BiolaSpp.) di Ekosistem Mangrove Desa Kahyapu Pulau Enggano. Jurnal Enggano,2 ( 1): 11-24.

Odum PE. 1996.Fundamentals Of Ecology (Dasar-Dasar Ekologi, Edisi Kretiga).Diterjemahkan oleh Samingan T. Yogyakarta: Gajah Mada University Press.

Saragi MS \&Desrita D. 2018. Ekosistem Mangrove Sebagai Habitat Kepiting Bakau (Scylla Serrata) di Kampung Nipah Desa Sei Nagalawan Kecamatan Perbaungan Serdang Bedagai Provinsi Sumatera Utara. Jurnal Ilmu-Ilmu Perairan Pesisir dan Perikanan, 7 (1): 84-90. 
Subiandono E, Bismark M, Heriyanto MN. 2013. Kemampuan

Avicennia Marina (Forsk.) Vierh.dan Rhizophora Apiculata B1. dalam Penyerapan Polutan Logam Berat (Absorption Ability Of Avicennia Marina (Forsk.) Vierh.And Rhizophora Apiculata B1.In Heavy Metal Pollutants). Jurnal Penelitian Hutan Dan Konservasi Alam, 10 (1) : 93-102.

Sugiyono. 2013. Metode Penelitian Kuantitatif, Kualitatif dan $R \& D$. Bandung: Alfabeta.

Suprayogi D, Siburian J, Hamidah A. 2014. Keanekaragaman Kepiting Biola (Kepiting Biola Spp.) di Desa Tungkal I Tanjung Jabung Barat. Biospecies, 7 (1):22-28.

Wardhani KN, Ihwan A, Nurhasanah. 2015. Studi Tingkat Keasaman Air Hujan Berdasarkan Kandungan Gas $\mathrm{CO}_{2}, \mathrm{SO}_{2}$, dan $\mathrm{NO}_{2}$ di Udara (Studi Kasus Balai Pengamatan Dirgantara Pontianak). Prisma Fisika, 3 (1):09-14. 